\title{
The Distribution of Enteroendocrine Cells in Small Intestine in Rats
}

\author{
Masoud Sadeghi ${ }^{1}$, Mohammad Reza Hojjati ${ }^{2}$, Farzad Sadeghi ${ }^{3}$ and Masoud Amiri ${ }^{4}$ \\ ${ }^{1}$ Department of Histology, Medical School, Shahrekord University of Medical Sciences, \\ Shahrekord, Iran \\ ${ }^{2}$ Department of Physiology, Medical School, Shahrekord University of Medical Sciences, \\ Shahrekord, Iran \\ ${ }^{3}$ Food Science and Technology, Research Institute of Food Science and Technology, Mashhad, Iran \\ ${ }^{4}$ Social Health Determinants Research Center and Department of Epidemiology and Biostatistics, \\ School of Health, Shahrekord University of Medical Sciences, Shahrekord, Iran
}

Correspondence should be addressed to: Masoud Amiri; masoud.amiri@yahoo.com

Received Date: 15 January 2013; Accepted Date: 28 January 2013; Published Date: 31 January 2014

Academic Editor: Margarita S. Campos

Copyright (C 2014 Masoud Sadeghi, Mohammad Reza Hojjati, Farzad Sadeghi and Masoud Amiri. Distributed under Creative Commons CC-BY 3.0

\begin{abstract}
In an experimental study, the enteroendocrine cells (argentaffin and argyrophil) in the epithelium of small intestine in rat were identified and were counted using two specific staining methods; i.e., argentaffin method of Singh and argyrophilic reaction of Grimelius. A specific pattern of the argentaffin cells distribution was found in rat small intestine. While the maximum amount of these cells was at the proximal part of duodenum as well as the end part of ileum, a specific pattern for the distribution of argyrophil cells in the rat small intestine was not found. This study showed that the majority of enteroendocrine cells in the epithelium of rat small intestine are argentaffin cells.
\end{abstract}

Keywords: Small intestine, Enteroendocrine cells, Argentaffin cells, Argyrophil cells.

\section{Introduction}

The mammalian small intestine structure is composed of four layers or tunicae: the mucosa, submucosa, muscularis and the serosa ${ }^{1}$. This organ is spread with the complex monolayer epithelium, which is composed of a number of distinct differentiated cell types. Four principal cells in intestinal epithelium are: absorptive enterocytes, goblet cells, paneth cells and enteroendocrine cells ${ }^{2}$. This area is still interesting 3,4 .

Enteroendocrine cells were first observed by Heidenhain in rabbits' and dogs' stomachs in1870. Soon after, these cells were identified in the entire gastrointestinal tract of numerous animal species 5. Their basal location in the epithelium and the presence of secretory granules concentrated at the cell base 
suggested that they were endocrine cells, releasing their secretions into the lamina propria and not into the intestinal lumen ${ }^{6}$. In 1905, Schmidt recognized these cells in the duodenum and named them as chromaffin cells because of their ability to bind to potassium dichromate.

In 1907, Ciaccio attributed chromaffin reaction to adrenalin and named those cells, which he found in gastric epithelium, as enterochromaffin cells. In1914, Masson discovered argentaffin reaction in the cells, and then in 1952, the amine located in the argentaffin cells was identified as serotonin. In1968, Pearse called this family of highly specific cells as the APUD system 2. Enteroendocrine cells represent less than $1 \%$ of cells in the intestinal mucosa 7. Generally, they are small pyramidal cells with clear, unstained cytoplasm. Granules in basal cytoplasm have been demonstrated by light microscopy ${ }^{8}$. At least 16 different enteroendocrine cells have been identified in the gastro-intestinal tract, based on their principal neuroendocrine products $8-10$. These cells secret peptide hormones, and are found scattered throughout the epithelium ${ }^{11}$. The endocrine products in the gut consist of more than 30 hormones. These hormones may act as acute metabolic hormones, local growth factors, and neuromodulators. The cells are dispersed in their hundreds of thousands between epithelial cells of the mucosa. The largest number of secretory granules is located along the basement membrane surface of the cells, where they can be released into nearby blood vessels to circulate and act as classical endocrine hormones. The substances that have been identified in enteroendocrine cells included: 5-hydroxy-tryptamine (serotonin), somatostatin, glucagon/glicentin, cholecystokinin, gastrin, motilin, secretin, neurotensin, substance $\mathrm{p}$, gastric inhibitory polypeptide and $ß$-endorphin ${ }^{6}$. These cells were named according to their staining properties; enterochromaffin, argentaffin and argyrophil 5. However, in light microscopic observations, the distinction between the argentaffin and argyrophil cells of the alimentary tract is based on histochemical procedures.
In general, based on chemical reactions, these cells are divided into three classes as following:

1. Chromaffin Cells: These cells contain granules that have affinity for chrome salts, and their granules become brown after fixation in a dichromate solution.

2. Argentaffin Cells: These cells have the ability to reduce silver solutions with the production of insoluble black metallic silver without the assistance of an external reducing agent.

3. Argyrophil Cells: In these cells, silver precipitates only in the presence of a reducing agent, usually hydroquinone 10 .

In general, cells which give the argentaffin reaction are also argyrophilic, but argyrophil cells do not give the argentaffin reaction 12 . However, these terms are extremely confusing and arbitrary. For example, chromaffin cells show argentaffin staining, if the tissue is fixed in formalin. Argentaffin cells in the small bowel show a positive chromaffin reaction, if the tissue is fixed in a formalin-dichromate mixture ${ }^{10}$.

The distribution of enteroendocrine cells in alimentary tract has been studied in numerous papers 13 however, the results are not consistent with each other. In this study, we tried to study the distribution of these cells by two specific staining methods.

\section{Material and Methods}

In this study, 28 pathogen-free Sprague Dawley male rats weighting between $180 \mathrm{~g}$ to $230 \mathrm{~g}$ were chosen. Local Ethics Committee has accepted the protocol of this study. Animals were given food and water ad libitum and were maintained in constant light. Animals were kept out of food for 48 hours, but they had free access to the water. Then the animals were deeply anesthetized with chloroform and were killed by cervical fracture. The abdomen was cut open and their small intestine was quickly removed and was 
measured accurately. Segments of organ, approximately $1 \mathrm{~cm}$ in length, were cut at the zones $0-1 \%, 6.2 \%, 12.5 \%$ (duodenum), $25 \%$ and $50 \%$ (jejunum), $75 \%$ and $99-$ 100\% (ileum).

Samples were put in formalin-salin, $10 \%$ for each segment of each rat, and stayed for 24 hours at laboratory temperature. After that, the samples were dehydrated in a graded ethanol series, cleared in xylene and embedded transversically in melted paraffin. Paraffin embedded specimens were sectioned at $5 \mu \mathrm{m}$ thickness, using a rotary microtome.

Following, staining methods were applied to paraffin sections; Hematoxylin \& Eosin (H\&E), Singh argentaffin method and Grimelius argyrophil technique. From each specimen, one section was selected for Hematoxylin \& Eosin, five serial sections for Singh argentaffin method, and other five serial sections for Grimelius argyrophilic reaction ${ }^{10}$.

The first selected section was being used for staining by routine H\&E method and if the section areas were transversically suitable, other sections would have been stained with specific staining methods, otherwise, embedding stages were repeated. After preparing smears, cell count was performed as following:

Argentaffin and argyrophil cells were counted in the stained sections taken from various portions. Counting was performed at a total magnification of $400 \times$ and included cells with definitely visible stained granules, only. Results were expressed as the mean of cell number per each area of the gut. Data were analyzed using T-test and the significant level of $5 \% \quad(\mathrm{P}<0.05)$ was used as the minimum acceptable probability for the difference between groups.

\section{Results}

Throughout the entire rat small intestine, those cells which had been stained by Grimelius technique for argyrophilia and Singh argentaffin reaction 10 could be observed. Cells were scattered as single elements among a large predominant population of epithelial non-endocrine cells within the columnar epithelium of the gut (Figure 1 and figure 2).

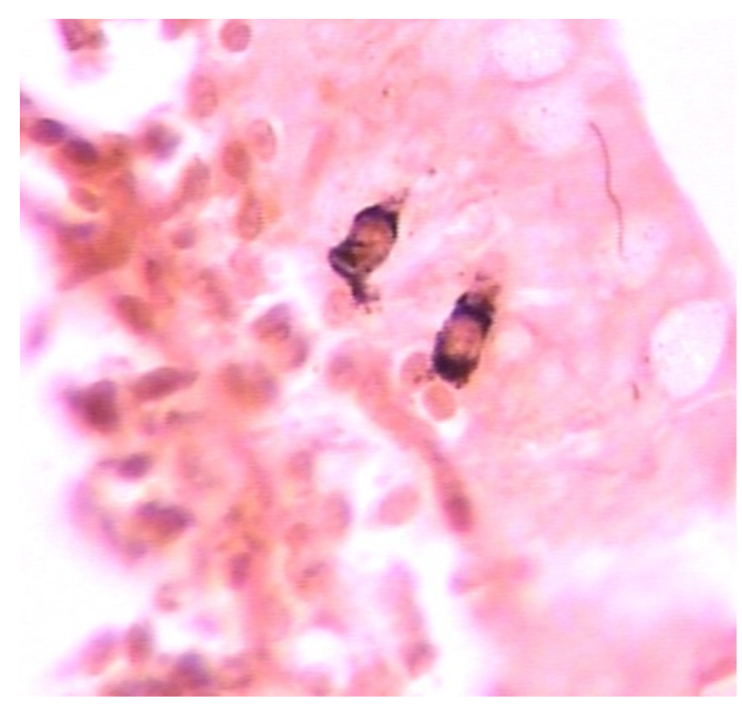

Figure 1. Singh Method Positive Enteroendocrine Cells (Argentaffin Cells) 


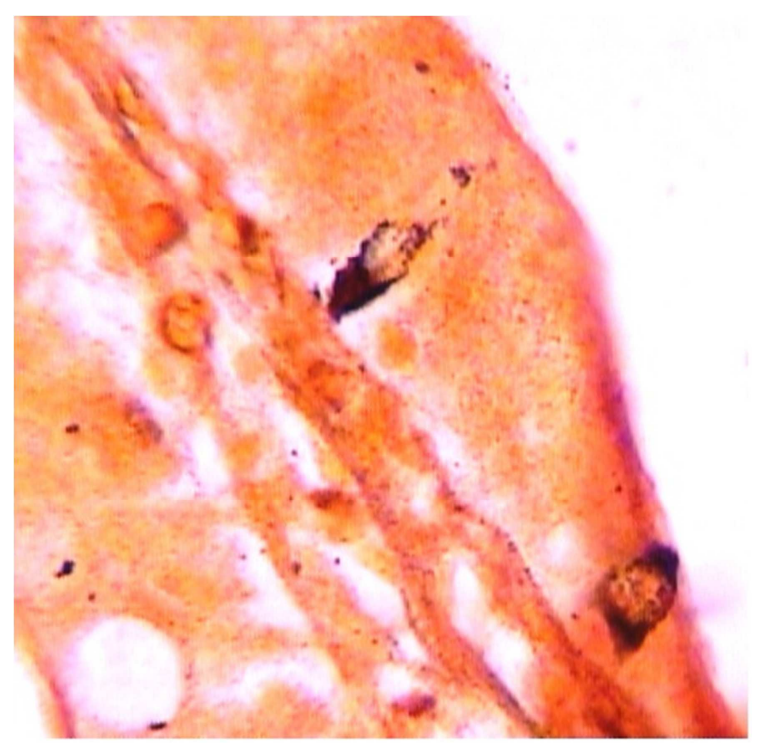

Figure 2. The Grimelius Positive Enteroendocrine Cells (Argyrophil Cells)

Grimelius positive cells were the most frequently found in the first part of the duodenum and were gradually decreased toward the jejunum, but finally they were increased slightly in the end portion of the ileum. In addition, a slight increase in these cells was shown in the middle part of the jejunum.
Because argentaffin cells participate in argyrophilic reaction, the mean number of Grimelius positive cells was calculated for each paraffin embedded sample as a whole number of enteroendocrine (argentaffin+argyrophilic) cells (table1).

Table 1- The Grimelius Positive Enteroendocrine Cells (Argentaffin+Argyrophil) in Various Sections of Rat Small Intestine

\begin{tabular}{|l|l|l|}
\hline $\begin{array}{l}\text { Small intestine section } \\
(\text { mean } \pm \text { S.D. })\end{array}$ & $\begin{array}{l}\text { Comparison section (mean } \pm \\
\text { S.D.) }\end{array}$ & P-value \\
\hline $0.1(150 \pm 9.21) \%$ & $6.2(67 \pm 8.35) \%$ & $<0.001$ \\
$6.2(67 \pm 8.35) \%$ & $12.5(59 \pm 5.11) \%$ & $<0.001$ \\
$12.5(59 \pm 5.11) \%$ & $25(45 \pm 6.12) \%$ & $<0.001$ \\
$25(45 \pm 6.12) \%$ & $50(51 \pm 9.14) \%$ & $<0.2$ \\
$50(51 \pm 9.14) \%$ & $75(46 \pm 8.94) \%$ & $<0.05$ \\
$75(46 \pm 8.94) \%$ & $99-100(67 \pm 8.47) \%$ & $<0.001$ \\
$*$ S.D. = Standard Deviation &
\end{tabular}

In the rat small intestine, Singh positive (argentaffin) cells were the most numerous cells in the first part of the duodenum and then their numbers were decreased toward the ileum and finally they were increased in the end part of the ileum.
Mean number of Singh method positive cells was calculated for each paraffin embedded sample, as pure argentaffin cells (table2). 
Table 2- The Singh Method Positive Enteroendocrine Cells (Argentaffin) in Various Sections of Rat Small

\begin{tabular}{|l|l|l|}
\hline $\begin{array}{l}\text { Small intestine section } \\
(\text { mean } \pm \text { S.D. })\end{array}$ & $\begin{array}{l}\text { Comparison section } \\
\text { (mean } \pm \text { S.D.) }\end{array}$ & P-value \\
\hline $0.1(141 \pm 9.06) \%$ & $6.2(56 \pm 3.69) \%$ & $<0.001$ \\
$6.2(56 \pm 3.69) \%$ & $12.5(48 \pm 2.85) \%$ & $<0.001$ \\
$12.5(48 \pm 2.85) \%$ & $25(42 \pm 5.32) \%$ & $<0.001$ \\
$25(42 \pm 5.32) \%$ & $50(37 \pm 6.67) \%$ & $<0.01$ \\
$50(37 \pm 6.67) \%$ & $75(33 \pm 7.46) \%$ & $<0.05$ \\
$75(33 \pm 7.46) \%$ & $99-100(57 \pm 7.43) \%$ & $<0.001$ \\
\hline * S.D. = Standard Deviation &
\end{tabular}

For assessing the actual number of argyrophilic cells in specimens, we compared the results in table 1 and table 2 and new results were reported as true argyrophil cells (table3).

Table 3- The Enteroendocrine Cells (True Argyrophil) in Various Sections of Rat Small Intestine

\begin{tabular}{|l|l|l|}
\hline $\begin{array}{l}\text { Small intestine section } \\
(\text { mean } \pm \text { S.D. })\end{array}$ & $\begin{array}{l}\text { Comparison section (mean } \pm \\
\text { S.D.) }\end{array}$ & P-value \\
\hline $0.1(9 \pm 1.79) \%$ & $6.2(11 \pm 5.00) \%$ & $<0.1$ \\
$6.2(11 \pm 5.00) \%$ & $12.5(11 \pm 6.12) \%$ & $<0.1$ \\
$12.5(11 \pm 6.12) \%$ & $25(12 \pm 4.20) \%$ & $<0.5$ \\
$25(12 \pm 4.20) \%$ & $50(14 \pm 4.12) \%$ & $<0.1$ \\
$50(14 \pm 4.12) \%$ & $75(13 \pm 5.61) \%$ & $<0.5$ \\
$75(13 \pm 5.61) \%$ & $99-100(10 \pm 4.32) \%$ & $<0.05$ \\
\hline
\end{tabular}

Percentages of argentaffin and argyrophil cells in each zone of small intestine were calculated and reported in table 4.

Table 4- Argentaffin and Argyrophil Cells in Three Main Parts of Rat Small Intestine

\begin{tabular}{|l|l|l|}
\hline $\begin{array}{l}\text { Part of small intestine } \\
\text { Number) }\end{array}$ & $\begin{array}{l}\text { Argentaffin cells } \\
(\%)\end{array}$ & Argyrophil cells (\%) \\
\hline $\begin{array}{l}\text { Duodenum (276) } \\
\text { Jejunum (105) }\end{array}$ & $\begin{array}{l}245(88.77) \\
79(75.24)\end{array}$ & $31(11.23)$ \\
Ileum (113) & $90(79.65)$ & $23(24.76)$ \\
\hline All three parts 494) & $414(83.8)$ & $80(16.2)$ \\
\hline
\end{tabular}

\section{Discussion}

The purpose of this study was to recognize the enteroendocrine cells and their distributions in the rat small intestine mucosa, using two specific staining methods. Argentaffin and argyrophil cells were counted in tissue sections of seven zones on longitudinal axis of rat small intestine, from initial part of duodenum (zone $0-1 \%$ of small bowel) toward the end of ileum (zone 99-100\%). In addition, the distribution of enteroendocrine cells was evaluated in these areas.

The obtained results from this study demonstrated that the most frequent numbers of argentaffin cells was found in the cranial end of duodenum. We also found a severe reduction of these cells in zone $6.2 \%$ and also a gradual decrease occurred toward the ileum. Finally, a 
significant increase was seen in the number of these cells in the end part of ileum $(\mathrm{P}<0.05)$. Our results demonstrated that the distribution of argentaffin cells in rat small intestine mucosa has a specific pattern, which is consistent with the previous results reported by Josephson and Altmann ${ }^{14}$.

On the other hand, our observations suggest that the distribution of argyrophil cells in rat small intestine does not have a specific pattern because they show a "wave-shaped" pattern.

Toner P.G found that the majority of enteroendocrine cells in small intestine were argentaffin cells 12 . This is in consistence with the results reported in present study, in which we found that $83.8 \%$ of enteroendocrine cells in rat small intestine are argentaffin cells and 16.2\% are argyrophil cells.

Our results are not consistent with the finding reported by Schmidt and Cordier in which they reported a monotonous distribution of argentaffin cells in the gut epithelium ${ }^{8}$. Hamperl showed that these cells are most frequent in duodenum, but their numbers are decreased toward the end of the gut in human ${ }^{15}$. We found similar results in rat small intestine. Our data are also consistent with previous data, in which a gradient decrease in the number of argentaffin cells has been shown from the first to the end part of the gut by argentaffin reaction ${ }^{14}$.

Nichols \& Co-workers reported that $6 \%$ of mouse duodenal enteroendocrine cells were argyrophilic ${ }^{16}$; however we observed that these cells are more than $11 \%$. In agreement with Nichols, in our study the number of argentaffin cells also was more than argyrophilic cell.

Conflict of interest: The authors have no conflicts of interest.

This article is a part of a master's thesis at Isfahan University of Medical Sciences with thesis number 2445 .
Authors' contributions: M Sadeghi: study concept and design; acquisition of data; analysis and interpretation of data; drafting of the manuscript; study supervision; MR Hojjati: drafting of the manuscript; critical revision of the manuscript for important intellectual content; F Sadeghi: study concept and design; acquisition of data; analysis and interpretation of data; drafting of the manuscript; study supervision; and M Amiri: drafting of the manuscript; critical revision of the manuscript for important intellectual content; statistical analysis; study supervision.

\section{References}

1. Ponder, B. A., Schmidt, G. H., Wilkinson, M. M., Wood, M. J., Monk, M. \& Reid, A. (1985). "Derivation of Mouse Intestinal Crypts from Single Progenitor Cells," Nature. Feb 21-27; 313(6004):689691.

2. Roth, K. A., Hertz, J. M. \& Gordon, J. I. (1990). "Mapping Enteroendocrine Cell Populations in Transgenic Mice Reveals an Unexpected Degree of Complexity in Cellular Differentiation within the Gastrointestinal Tract," The Journal of Cell Biology, May; 110(5):1791-1801.

3. Formeister, E. J., Sionas, A. L., Lorance, D. K., Barkley, C. L., Lee, G. H. \& Magness, S. T. (2009). "Distinct SOX9 Levels Differentially Mark Stem/Progenitor Populations and Enteroendocrine Cells of the Small Intestine Epithelium," American Journal of Physiology - Gastrointestinal and Liver Physiology. May; 296(5):G1108-1118.

4. Sei, Y., Lu, X., Liou, A., Zhao, X. \& Wank, S. A. (2011). "A Stem Cell MarkerExpressing Subset of Enteroendocrine Cells Resides at the Crypt Base in the Small Intestine," American Journal of Physiology - Gastrointestinal and Liver Physiology. Feb; 300(2):G345-356.

5. Forssmann, W. G., Orci, L., Pictet, R., Renold, A. E. \& Rouiller, C. (1969). "The Endocrine Cells in the Epithelium of 
the Gastrointestinal Mucosa of the Rat: An Electron Microscope Study," The Journal of Cell Biology, Mar; 40(3):692715.

6. Fawcett, D. W. (1993). Bloom and Fawcett: A Textbook of Histology, 12th Ed: Chapman \& Hall.

7. Aiken, K. D., Kisslinger, J. A. \& Roth, K. A. (1994). "Immunohistochemical Studies Indicate Multiple Enteroendocrine Cell Differentiation Pathways in the Mouse Proximal Small Intestine," Developmental Dynamics, Sep; 201(1):63-70.

8. Odartchenko, N. H. C., Ruzicka, J. \& Weber, E. (1970). "Cytokinetics of Argentaffin Cells in Mouse Intestinal Mucosa," Virchows Archiv B Cell Pathology Zell-Pathologie. 6(1):132136.

9. Roth, K. A. \& Gordon, J. I. (1990). "Spatial Differentiation of the Intestinal Epithelium: Analysis of Enteroendocrine Cells Containing Immunoreactive Serotonin, Secretin, and Substance $\mathrm{P}$ in Normal and Transgenic Mice," Proceedings of the National Academy of Sciences of the United States of America, Aug;87(16):6408-6412.

10. Bancroft, J. D. (1990). 'Theory and Practice of Histological Techniques,' Edinburgh.

11. Day, R. M. (2006). "Epithelial Stem Cells and Tissue Engineered Intestine," Current Stem Cell Research \& Therapy, Jan; 1(1):113-120.
12. Toner, P. G. (1964). "Fine Structure of Argyrophil and Argentaffin Cells in the Gastro-Intestinal Tract of the Fowl," Zeitschrift für Zellforschung und Mikroskopische Anatomie, Sep 3; 63: 830-839.

13. Okamoto, T. \& Fujii, S. (1980). "An Electron Microscopic Study on Endocrine Cells in the Pyloric Region of the Duck," Nihon Juigaku Zasshi. The Japanese Journal of Veterinary Science, Apr; 42(2):169-176.

14. Josephson, R. L. \& Altmann, G. G. (1973). "Distribution of Diazo-Positive (Argentaffin) Cells in the Small Intestine of Rats of Various Ages," American Journal of Anatomy, Jan; 136(1):15-22.

15. Hamperl, H., Kaufmann, C., Ober, K. G. \& Schneppenheim, P. (1958). "Erosion of the Portio; Formation of Pseudoerosion, Ectropion and Pavement Cell Epithelialization of the Cervical Glands on the Surface of the Portio," Virchows Archiv für pathologische Anatomie und Physiologie und für klinische Medizin; 331(1):5171.

16. Nichols, D. B., Cheng, H. \& Leblond, C. P. (1974). "Variability of the Shape and Argentaffinity of the Granules in the Enteroendocrine Cells of the Mouse Duodenum," Journal of Histochemistry \& Cytochemistry. Oct; 22(10):929-944. 